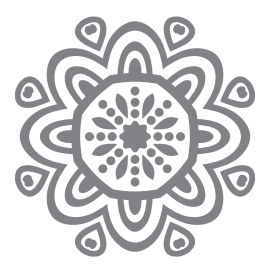

\title{
Konsep Ilmu Ladunni dalam Upaya Penafsiran Al-Quran
}

\author{
Abd. Muid N. ${ }^{1}$, Abdul Rouf 2, dan Hasanuddin ${ }^{3}$ \\ 1), 2) Dosen UIN Syarif Hidayatullah Jakarta DPK Institut PTIQ Jakarta \\ ${ }^{3)}$ Magister Ilmu Al-Quran dan Tafsir Institut PTIQ Jakarta \\ Email: ${ }^{1)}$ balesaloe@gmail.com, ${ }^{2)}$ abdulrouf16@yahoo.com
}

\begin{abstract}
Ladunni's science becomes an inseparable part and becomes a necessity. Thus, the Ladunni Science demonstrates the importance of its role in the interpretation of the Qur'an and the importance of understanding this type of scholarship (science of Ladunni) for the exegetes. In textual matters, the Ladunni Science functionally has two main working areas, namely the text area (object or internal) and the review region (subject or external). In the discourse of tafseer, the text is the Qur'an and the reviewer is the mufassir (as well as the reader). This thesis also found three functions, contributing to the text of the Qur'an, namely: a. Reveals the inner things (asrar) of the object; $b$. Achieves the highest point of human effort in understanding texts and objects, and c. Avoid inaccurate understanding and meaning of a text or object. While the function of the mufassir also there are three, namely: $a$. As moral control for the perpetrators, $b$. Showing His greatness and power at the same time reveals the limitations of the subject's ability, and c. Ma'rifat bi-l was.
\end{abstract}

Keywords: ladunni science, tafsîr, tasawwuf 


\section{A. Pendahuluan}

Dalam hadits Huzaifah, ketika Rasulullah menggambarkan perpecahan dan pertentangan sesudahnya, Huzaifah bertanya: "Ya Rasulullah apa yang kau perintahkan kepadaku, jika kami mengalami hal itu." Ia berkata: "Pelajarilah kitab Allah, dan amalkanlah apa yang ada di dalamnya. Disitu ada jalan keluarnya." Kata Huzaifah: "Aku ulangi pertanyaan itu tiga kali, dan Rasul s.a.w. menjawabnya tiga kali: Pelajarilah kitabullah, dan amalkan apa yang ada di dalamnya, karena disitu ada keselamatan.” Berkata Ali r.a.: "Barangsiapa memahami al-Qur'an, ia menafsirkan sejumlah ilmu." Dengan itu Ali mengatakan bahwa al-Qur'an menunjukkan pokok pokok seluruh ilmu. Ibnu Abbas r.a. berkata tentang arti firman Allah Ta'ala, "Siapa yang diberi hikmah, dia telah diberi kebaikan yang banyak ", sebagai pemahaman tentang al-Qur'an. Allah SWT berfirman: "Kami berikan pemahaman kepada Sulaiman, dan keduanya Kami beri hukum dan ilmu. Allah menamai apa yang diberikan kepada keduanya ilmu dan hukum, tetapi mengkhususkan kepada Sulaiman pemahaman, dan menjadikannya sebagai pendahulu hukum dan ilmu. Ini semua menunjukkan bahwa dalam pemahaman terhadap makna al-Qur'an terdapat bidang yang luas dan lapangan yang lebar, dan bahwa membatasi al-Qur'an pada yang manqul dari tafsir zahir, bukanlah akhir pengetahuan. ${ }^{1}$

Disinilah peran ilmu pengetahuan, karena Allah SWT telah mengajarkan kepada manusia sebuah ilmu pengetahuan, yaitu dengan cara, pertama: "Mengajarkan dengan pena atau tulisan," kedua: "Melalui pengajaran secara langsung tanpa alat, cara yang kedua ini dikenal dengan istilah ilmu Laduni." Disini dapat dipahami bahwa, untuk mendapatkan ilmu pengetahuan seseorang harus belajar dan membaca. Hal itu sudah jelas ketika manusia ingin mengetahui sebuah informasi maka ia harus belajar, akan tetapi Allah SWT juga telah mengajarkan manusia apa yang belum di ketahuinya, yang dipahami dengan ilmu laduni. Ilmu ini hanyalah diberikan kepada seorang hamba yang benar-benar bertakwa kepada Allah SWT, seperti Nabi Khidir sebagaimana mendapatkan ilmu tersebut. ${ }^{3} \mathrm{Hal}$ ini seperti dijelaskan dalam surat al-Kahfi/18:65:

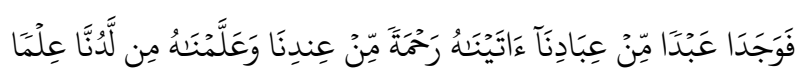

${ }^{1}$ Al-Ghazali, Ihya Ulumuddin, hal, 261.

2 M. Quraish Shihab, Tafsir al-Misbah Pesan dan Kesan al-Qur'an, (Jakarta: Lentera Hati, 2002), hal. 481.

${ }^{3}$ Syaikh Muhammad Ali Ash-Shabuni, Syafwatutu Tafasir, Terj. Yasin. Vol. 3 (Jakarta: Pustaka al-Kautsar, 2011), hal. 305. 
"Lalu mereka bertemu dengan seorang hamba di antara hamba-hamba Kami, yang telah Kami berikan kepadanya rahmat dari sisi Kami, dan yang telah Kami ajarkan kepadanya ilmu dari sisi Kami" (Q.S. al-Kahfi/18:65)

Menurut ahli tafsir hamba disini ialah "Khidir", sedangkan yang dimaksud dengan rahmat disini ialah "Wahyu dan kenabian". Sedangkan yang dimaksud dengan ilmu ialah "ilmu tentang yang ghaib". ${ }^{4}$

Ilmu Laduni pada masa klasik dipahami sebagai ilmu ghaib karena ditafsiri secara tekstual saja. Pada masa ini penafsiran berbasis Quasi kritis, dan didominasi dengan tafsir bil ma'tsur yang dimulai sejak Nabi Muhammad SAW sampai generasi ulama' Mutaqaddimin atau sejak kemunduran Islam yaitu jatuhnya Baghdad pada tahun $656 \mathrm{H} / 1258 \mathrm{M}$. sedangkan pada zaman modern hingga sekarang yang dimulai sejak gerakan modern Islam di Mesir oleh Jamaluddin alAfgani pada tahun $1254 \mathrm{H} / 1838 \mathrm{M}$. para mufassir modern Islam di Mesir dalam menafsirkan al-Qur'an lebih menjelaskan bahwa Islam tidak bertentangan dengan ilmu pengetahuan dan kemoderenan. Islam adalah agama universal yang sesuai dengan seluruh bangsa pada semua masa dan setiap tempat. ${ }^{5}$

Maka ilmu laduni di pahami, ilmu yang diberikan Allah SWT. Artinya seluruh ilmu baik yang ghaib dan yang empiris. Karena pada modern hingga sekarang, tidak dipahami secara tekstual saja, melainkan juga di kaitkan dengan berbagai ilmu dan perekembangan zaman, seperti yang dikatakan oleh ulama sufi "Orang yang mendekatkan diri kepada Allah SWT ( $M a$ 'rifah) niscaya ia akan mendapatkan anugerah yang akan diberikan kepadanya."6

Dalam ar-risalah al-ladunniyah, bahwa ilmu laduni adalah penggambaran jiwa yang berbicara (an-nafs an-natiqah) dan jiwa yang tenang menghadapi hakikat berbagai hal. Seorang yang 'alim adalah samudera yang berpengetahuan dan memiliki penggambaran. Sedangkan objek ilmu adalah zat sesuatu yang ilmunya terukir dalam jiwa. ${ }^{7}$ Artinya ilmu Laduni bisa didapatkan jika seseorang itu benar-benar bertakwa kepada Allah SWT dan melaksanakan perintahnya sehingga orang tersebut bisa mencapai maqam ma'rifah melalui siraman zikir maka orang tersebut akan bisa mendapatkan ilmu laduni.

Al-Zarqani, penyusun Manahil al-'Irfan fi 'Ulum al-Qur'an, memberikan definisi mengenai konsep Ilmu Laduni, yakni bahwa ia adalah ilmu pemberian Allah bagi para aplikator pengetahuan yang dimilikinya. Sebagaimana pula yang

\footnotetext{
${ }^{4}$ Syaikh Muhammad Ali Ash-Shabuni, Syafwatutu Tafasir, hal. 306.

${ }^{5}$ Nasaruddin Baidan, Perkembangan Tafsir al-Qur'an di Indonesia (Solo: Tiga Serangkai, 2003), hal. 15.

${ }^{6}$ Ahmad bin Muhammad al-Dhimyathi, Kaum Sufi dan Pemikirannya (Bandung: Nusa Medua, 2005), hal. 18.

7 Al-Ghazali, Ar-Risalah al-Ladunniyyah, (Terj.) (Yogyakarta: Mitra Pustaka, 2004), hal. 9.
} 
terurai di dalam al-Itqan, al-Zarqani juga menekankan bahwa ilmu ini tidak akan diperoleh seseorang yang di hatinya masih diliputi berbagai hijab seperti bid'ah, sombong, hawa nafsu, dan sebagainya. ${ }^{8}$ Ini didasarkan firman Allah SWT. pada Q.S. al-A'raf/7: 146, yakni:

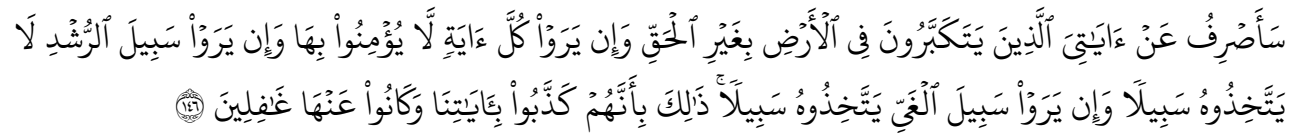

"Aku akan memalingkan orang-orang yang menyombongkan dirinya di muka bumi tanpa alasan yang benar dari tanda-tanda kekuasaan-Ku. Mereka jika melihat tiap-tiap ayat (Ku), mereka tidak beriman kepadanya. Dan jika mereka melihat jalan yang membawa kepada petunjuk, mereka tidak mau menempuhnya, tetapi jika mereka melihat jalan kesesatan, mereka terus memenempuhnya. Yang demikian itu adalah karena mereka mendustakan ayat-ayat Kami dan mereka selalu lalai dari padanya. (Q.S. al-A'raf /7: 146)

Sementara itu, M. Husain al-Zahabi, setelah melakukan pemaparan konsep yang sama dengan al-Suyuthi, menambahkan dasar pijakan konsepnya dengan surat Q.S. al-Baqarah/2:282, yakni:

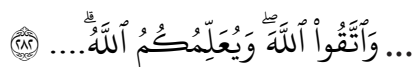

"...Dan bertakwalah kepada Allah; Allah mengajarmu...." (Q.S. al-Baqarah/2: 282)

Ilmu ladunni atau huduri adalah ilmu yang proses perolehannya melalui proses pencerahan oleh hadirnya cahaya Ilahi dalam qalb. Dengan hadirnya cahaya Ilahi itu semua pintu ilmu terbuka menerangi kebenaran, terbaca dengan jelas, dan terserap dalam kesadaran intelek, seakan-seakan orang tersebut memperoleh ilmu dari Tuhan secara langsung. Di sini Tuhan bertindak sebagai pengajarnya. ${ }^{9}$ Kemungkinan proses pencerahan ini didasarkan pada surat al-Baqarah/2:31 dan surat al-'Alaq/96:3-5, yakni:

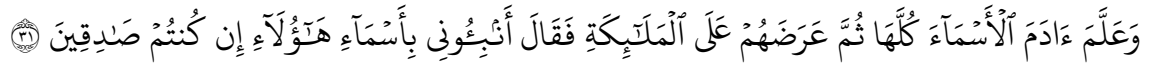

"Dan Dia mengajarkan kepada Adam nama-nama (benda-benda) seluruhnya, kemudian mengemukakannya kepada para Malaikat lalu berfirman: "Sebutkanlah

${ }^{8}$ Muhammad 'Abd al-'AzIm al-Zarqani, Manahil al-'Irfan fi 'Ulum al-Qur'an, Jilid II (Beirut: Dar al-Fikr, t. th.), hal. 51.

9 Musa Asy'arie, Filsafat Islam: Sunnah Nabi Dalam Berpikir (Jogjakarta: LESFI, Cet. III ; 2002), hal. 54. 
kepada-Ku nama benda-benda itu jika kamu mamang benar orang-orang yang benar." (Q.S. al-Baqarah/2: 31)

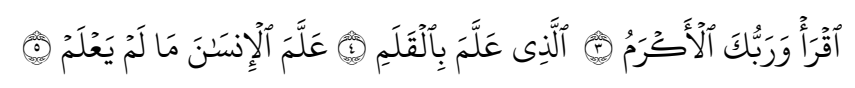

"Bacalah, dan Tuhanmulah Yang Maha Pemurah, Yang mengajar (manusia) dengan perantaran kalam, Dia mengajar kepada manusia apa yang tidak diketahuinya." (Q.S. al-'Alaq/96: 3-5)

Adapun cara memperolehnya, Musa Asy'ari memberikan keterangan bahwa seseorang yang hendak mendapatkan Ilmu Huduri harus membersihkan qalb dan mengosongkan egoisme dan keakuannya ke titik nol, sehingga ia berdiri di hadapan Tuhan seperti seorang murid berhadapan dengan gurunya. Tuhan kemudian hadir membukakan pintu kebenaran dan manusia masuk ke dalamnya, memasuki kebenaran. Dan ketika ia keluar, maka ia menjadi menyatu dengan kebenaran yang telah dimasukinya. Selain itu, orang yang sedang berproses membersihkan qalb dan mengosongkan egoisme dan keakuannya ke titik nol mesti memiliki keikhlasan total demi mencapainya. ${ }^{10}$

Al-Ghazali dalam karyanya al-Risalat al-Ladunniyyah yang diterjemahkan oleh M. Yaniyullah dengan judul Ilmu Laduni menyebutkan bahwa Ilmu Ladunni adalah rahasia-rahasia cahaya ilham. Ia akan menjadi ada setelah adanya pelurusan sebagaimana firman Allah SWT dalam surat al-Syams/91: 7, yakni:

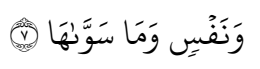

"dan jiwa serta penyempurnaannya (ciptaannya). (Q.S. al-Syams/91: 7)

Al-Ghazali meyebutkan bahwa ada tiga cara guna memperoleh Ilmu Ladunni. Pertama, ilmu tersebut diperoleh karena mendapat anugerah keberuntungan dari Allah. Kedua, ilmu tersebut diperoleh melalui jalan riyadah (mujahadah atau latihan) yang benar, proses muraqabah (ber-ihsan, memposisikan diri untuk seakan-akan melihat Allah ketika beribadah, atau, jika tidak, tetap ingat bahwa ia selalu diawasi oleh Allah) yang benar. Ketiga, ilmu diperoleh melaui tafakkur (berpikir). ${ }^{11}$ Khusus untuk riyadah, al-Gazali menyebutkan bahwa inti riyadah ada tiga hal (tahap), yaitu takhalli (melepaskan qalbu dari sifat-sifat tercela), tahalli (menghiasi kalbu dengan sifat-sifat terpuji), dan tajalli (membukakan tabir ketuhanan ke dalam qalbu). ${ }^{12}$

\footnotetext{
${ }^{10}$ Musa Asy'arie, Filsafat Islam: Sunnah Nabi Dalam Berpikir, hal. 56.

${ }^{11}$ Abu Hamid Muhammad al-Gazali,.Ilmu Laduni, terj. M. Yaniyullah, (Jakarta Selatan: Hikmah, Cet. I; 2003 M/ 1423 H), hal. 59-60.

${ }^{12}$ Abu Hamid Muhammad al-Gazali,.Ilmu Laduni, terj. M. Yaniyullah, hal. 74.
} 
Mehdi Ha'iri Yazdi memaparkan konsep Ilmu Laduni (beliau menyebutnya Ilmu Huduri) dengan mengambil dan mendasarkan prinsipnya pada pendapat Syihabuddin Suhrawardi dan Shadruddin Syirazi (Mulla Shadra) sebagai penerusnya. Bagi Suhrawardi, orang tidak bisa memiliki pengetahuan orang lain yang berada di luar realitas dirinya sendiri sebelum masuk dan mendalami pengetahuan tentang kediriannya sendiri yang tak lain adalah Ilmu Huduri. Ciri utama dari ilmu ini dikemukakan oleh Mulla Shadra, yaitu swa objektivitas, yakni apa yang sesungguhnya diketahui oleh subyek yang mengetahui dan apa yang sesungguhnya eksis dalam sendirinya adalah satu dan sama. Ini berarti semacam upaya untuk memahami diri sendiri, upaya membersihkan diri, dan upaya mengenal hakikat. Seseorang yang mengenal (hakikat) dirinya, ia mengenal Tuhannya. Seseorang yang mengenal Tuhannya, terbuka hatinya atas segala hal. ${ }^{13}$

Sementara itu Yunasril Ali menyebutkan bahwa Ilmu Ladunni adalah pengetahuan langsung yang dikaruniakan Allah kepada manusia tertentu, tanpa melalui pengajaran atau perantaraan guru. Kata "ladun" dalam bahasa Arab berarti di sisi. Term ini terdapat misalnya dalam Q.S. al-Kahfi/18: 65, yakni:

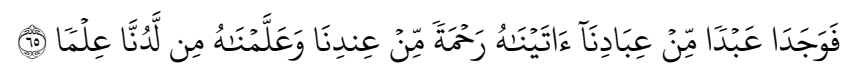

"Lalu mereka bertemu dengan seorang hamba di antara hamba-hamba Kami, yang telah Kami berikan kepadanya rahmat dari sisi Kami, dan yang telah Kami ajarkan kepadanya ilmu dari sisi Kami." (Q.S. al-Kahfi/18: 65)

Ayat ini mengkisahkan peristiwa yang terjadi antara Nabi Khidir dan Nabi

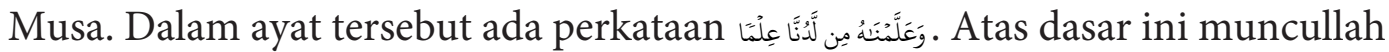
istilah Ilmu Ladunni. Menurutnya, ilmu ini bisa diperoleh siapa saja, asal ia berhasil memenuhi syarat-syaratnya yang di antaranya adalah membersihkan hati dan mensucikan jiwa.

\section{B. Konssep Ilmu Laduni}

Dalam ulasan dan komentarnya al-Suyuthi menunjukkan bahwa Ilmu Ladunni memiliki posisi yang penting dalam penafsiran. Ilmu Ladunni, menurutnya, merupakan ilmu yang berfungsi sebagai pembuka makna-makna al-Qur'an dan rahasia-rahasianya. Tanpa ini, al-Qur'an tidak akan menunjukkan makna sesungguhnya dari ayat-ayat-Nya berikut rahasia-rahasianya. Dalam

${ }^{13}$ Lawan dari ilmu jenis ini adalah al-'Ilm al-Husuli al-Irtisami, yaitu pengetahuan yang berdasarkan atas prinsip-prinsip kebenaran korespondensi atau representasional dan perolehan. Lihat Mehdi Ha'iri Yazdi, Ilmu Huduri: Prinsip-Prinsip Epistemologi dalam Filsafat Islam, terj. Ahsin Mohammad (Bandung: Mizan, 1994), dikutip dari Musa Asy’arie, Filsafat Islam..., hal. 72. 
keterangan yang lebih lanjut bahkan, sebagaimana yang dikutip pula oleh ahli-ahli Ulumul Qur'an seperti al-Zarqani, tidak adanya Ilmu Ladunni pada diri seseorang menjadikan ia terhalang dan terbelokkan dari makna yang sesungguhnya. ${ }^{14}$

Dari paparan di atas dapat diketahui dengan tepat posisi sebenarnya Ilmu Ladunni dalam penafsiran. Ilmu ini bukan bagian terpisah dan berhadapan dengan model penafsiran bi al-Ra'yi. Ia justru menjadi bagian yang tak terpisahkan dari perangkat pokok penafsiran tersebut. Memang pada beberapa hal Ilmu Ladunni memiliki kesamaan dengan pola penafsiran al-Isyari, namun Ilmu Ladunni lebih merupakan rangkaian proses, bukan semata-mata produk. Yang ditekankan bukan pada kuantitas makna yang diperoleh dengan jumlah yang terukur secara internempirik ${ }^{15}$, melainkan pada kualitas proses menuju Ilmu Ladunni. Sedangkan pola Isyari lebih memperlihatkan penekanan pada hasil prosesnya (hasil dari proses ber-Isyari, menangkap isyarat-isyarat ilahiah).

Berawal dari kisah Nabi Musa dan Nabi Khidir yang melakukan pencarian guna memperoleh ilmu yang belum di dapatkan Nabi Musa, yaitu Ilmu Ladunni, kemudian Nabi Musa berguru kepada Nabi Khidir dan pada saat itulah Nabi Khidir menujukkan ilmunya kepada Nabi Musa. Sebagaimana dijelaskan di dalam al-Qur'an Surat AlKahfi/18:60-65:

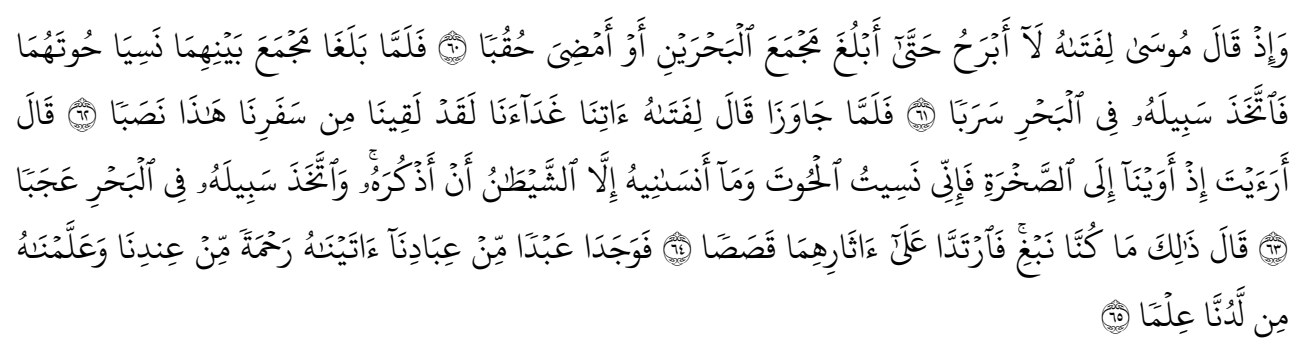

"Dan (ingatlah) ketika Musa berkata kepada muridnya: "Aku tidak akan berhenti (berjalan) sebelum sampai ke pertemuan dua buah lautan; atau aku akan berjalan sampai bertahun-tahun"

Maka tatkala mereka sampai ke pertemuan dua buah laut itu, mereka lalai akan ikannya, lalu ikan itu melompat mengambil jalannya ke laut itu

Maka tatkala mereka berjalan lebih jauh, berkatalah Musa kepada muridnya: "Bawalah kemari makanan kita; sesungguhnya kita telah merasa letih karena perjalanan kita ini”

${ }^{14}$ Jalaluddin al-Suyuthi, al-Itqon fi Ulum al-Qur'an (Beirut: Dar al-Kutub al-Ilmiyah, 1987 jil 2), hal. 285.

${ }^{15}$ Yang dimaksud dengan intern adalah produk-produk penafsiran terhadap ayat yang berasal dari isyarat-isyarat ilahiah, bukan ekses-ekses eksternal yang dialami oleh mufassir dan para pengkaji al-Qur'an. Sedangkan empirik berarti wujud nyata dari proses ber-Isyari berupa produk-produk penafsiran sebagaimana yang lazim terdapat pada kitab-kitab tafsir jenis Isyari. 
Muridnya menjawab: "Tahukah kamu tatkala kita mencari tempat berlindung di batu tadi, maka sesungguhnya aku lupa (menceritakan tentang) ikan itu dan tidak adalah yang melupakan aku untuk menceritakannya kecuali syaitan dan ikan itu mengambil jalannya ke laut dengan cara yang aneh sekali"

Musa berkata: "Itulah (tempat) yang kita cari". Lalu keduanya kembali, mengikuti jejak mereka semula

Lalu mereka bertemu dengan seorang hamba di antara hamba-hamba Kami, yang telah Kami berikan kepadanya rahmat dari sisi Kami, dan yang telah Kami ajarkan kepadanya ilmu dari sisi Kami." (Q.S. al-Kahfi/60-65)

Syekh Nawawi Al-Jawi di dalam tafsirnya menjelaskan murid Nabi Musa a.s. itu ialah Yusya 'bin Nun.dan yang dimaksud dengan hamba di sini ialah Khidhr, dan yang dimaksud dengan rahmat di sini ialah wahyu dan keNabian. sedang yang dimaksud dengan ilmu ialah ilmu tentang yang ghaib. ${ }^{16}$ Yaitu Ilmu yang tidak semua orang bisa mengetahui dan mendapatkannya. Sayyid Qutb menjelaskan beberapa ayat diatas tadi di dalam tafsir "Fi Dzilalil Quran" nya sebagai berikut, Nabi Musa berusaha mendapatkan ilmu dengan berguru kepada Nabi Khidir tetapi ilmu hamba yang saleh itu bukanlah ilmu seorang manusia yang sebabsebabnya jelas dan hasil-hasilnya dekat, sesungguhnya ia termasuk ilmu Ladunni tentang perkara Gaib, yang diajarkan oleh Allah kepadanya tentang qadar yang diinginkan-Nya untuk hikmah yang diinginkan-Nya.

Oleh karena itu Nabi Musa tidak akan mampu bersabar kepada hamba saleh itu bersama perilaku-perilakunya, walaupun dia seorang Nabi dan Rasul. Karena perilaku-perilaku hamba saleh tersebut yang tampak di permukaan kadangkala terbentur dengan logika akal yang lahiriah dan hukum-hukum lahiriah. Pasalnya, perilaku hamba yang saleh itu mengharuskan adanya pengertian dan pengetahuan tentang hikmah gaib yang ada dibaliknya, bila tidak memiliki bekal itu maka perilaku-perilaku tersebut tampak aneh dan pasti diingkari, sehingga hamba saleh yang telah diberi ilmu ladunni itu sangat khawatir kepada Nabi Musa, karena ia pasti tidak akan mampu bersabar atas keikutsertaanya dan tingkah lakunya. ${ }^{17}$

Dalam pada itu, kedudukan ilmu yang tinggi juga digambarkan oleh Allah pada kasus Nabi Sulaiman ketika ingin memindahkan singgasana Ratu Bilqis. Mulanya Ifrit, makhluk sebangsa Jin menawarkan kepada Nabi Sulaiman bahwa ia dapat memindahkan singgasana ratu Bilqis sebelum Nabi Sulaiman beranjak bangun, tetapi oleh oleh orang yang memiliki ilmu singgasana itu dapat dipindahkan sebelum Nabi Sulaiman mengalihkan pandangan. Karena kedudukan hal. 503.

${ }^{16}$ Syekh Nawawi Al-jawi, Marah Labid Tafsir An-Nawawi, (Surabaya: Al-Hidayah), Jilid I,

${ }^{17}$ Sayyid Muhammad Qutb, Tafsir Fi Zhilal Al-Quran, (Beirut: Dar Al-Syuruq, 1992), hal. 33. 
imu yang sedemikian rupa, maka ilmu diberikan kepada orang yang telah cukup memiliki kedewasaan. Seperti yang terjadi pada Nabi Musa as.

Dalam ayat lain al-Qur'an menggambarkan bahwa dengan ilmu, orang dapat berlaku arif sehingga memahami bahwa anugrah Allah berupa pahala hanya dapat digapai dengan kesabaran. Sebenarnya sulit sekali membuat suatu definisi yang pasti tentang ilmu, filsafat, dan agama. Hal ini disebabkan karena perbedaan sudut pandang, jenis bangsa dan agama yang dianut dari orang yang mendefinisikannya itu. Orang berkata bahwa si Fulan diberi gelar "Ulama" karena ia banyak mengetahui tentang segala urusan, baik itu urusan agama maupun urusan kemasyarakatan. Pokoknya ia serba tahu. Oleh sebab itu, ilmu secara umum dapat didefinisikan sebagai sesuatu yang melekat pada manusia dimana ia dapat mengetahui sesuatu yang asalnya tidak ia ketahui. Salah satu contoh sederhana, umpamanya si Fulan hari kemarin tidak dapat mengerjakan pekerjaan rumah yang ditugaskan oleh dosennya, yakni soal bahasa Arab, setelah ia diberitahu oleh gurunya dikelas, baru ia dapat mengerjakan soal itu, dan sekarang si Fulan dikatakan sudah mempunyai ilmu tentang soal bahasa Arab tadi. ${ }^{18}$

Dari gambaran di atas, dapat dikatakan bahwa secara umum ilmu itu berarti tahu. Ilmu itu adalah pengetahuan. Seseorang yang banyak ilmunya bisa dikatakan sebagai seorang ilmuwan, ulama, ahli pengetahuan dan lain sebagainya. Pada dasarnya pengetahuan mempunyai tiga kriteria, yaitu: (a) adanya suatu sistem gagasan dalam pikiran; (b) persesuaian antara gagasan itu dengan benda-benda sebenarnya; dan (c) adanya keyakinan tentang persesuaian itu.

Kita ambil sebuah contoh yang mudah. Katakanlah bahwa kita mengetahui adanya "bulan". Hal itu berarti bahwa di dalam pikiran kita ada suatu gagasan tentang adanya sebuah benda langit yang namanya bulan. Gagasan dalam pikiran itu bersesuaian dengan bulan yang betul-betul ada. Kita yakin bahwa bulan itu memang betul-betul ada. ${ }^{19}$

Ada beberapa hal dimana filsafat dan ilmu pengetahuan (sains) dapat saling bertemu. Dalam beberapa abad terakhir, filsafat telah mengembangkan kerjasama yang baik dengan ilmu pengetahuan. Banyak diantara filsuf terkenal yang telah memberikan kontribusinya kepada sains. Sebagai contoh, Leibniz ikut serta dalam penemuan "hitung differensial". Filsafat dan ilmu pengetahuan kedua-duanya menggunakan metode pemikiran reflektif dalam usaha untuk menghadapi fakta-fakta dunia dan kehidupan. Keduanya menunjukkan sikap kritik, dengan pikiran terbuka dan kemauan yang tidak memihak, untuk

${ }^{18}$ Juhaya S. Praja, Aliran-aliran filsafat dan etika, (Jakarta: Prenada Media, Jakarta Timur, 2003, hal., 9 .

${ }^{19}$ Juhaya S. Praja, Aliran-aliran filsafat dan etika, hal. 10. 
mengetahui hakikat kebenaran. Mereka berkepentingan untuk mendapatkan pengetahuan yang teratur. ${ }^{20}$

Sebelum kita membedakan antara pengetahuan biasa yang disebut knowledge/common sense dan pengetahuan ilmiah yang disebut science, maka kita menelusuri dulu apakah arti dan definisi ilmu pengetahuan itu. Dalam "Ensiklopedi Indonesia" kita jumpai pengertian sebagai berikut: ilmu pengetahuan, suatu sistem dari pelbagai pengetahuan yang masing-masing mengenai suatu lapangan pengalaman tertentu, yang disusun sedemikian rupa menurut asas-asas tertentu, hingga menjadi kesatuan, suatu sistem dari pelbagai pengetahuan yang masingmasing didapatkan sebagai hasil pemeriksaan-pemeriksaan yang dilakukan secara teliti dengan memakai metode-metode tertentu (induksi, deduksi). ${ }^{21}$

Menurut epistemologi, setiap pengetahuan manusia itu adalah hasil dari berkontaknya dua macam besaran, yaitu:

a. Benda atau yang diperiksa, diselidiki dan akhirnya diketahui (obyek).

b. Manusia yang melakukan pelbagai pemeriksaan dan penyelidikan dan akhirnya mengetahui benda atau hal tadi (subyek).

Kata ilmu merupakan terjemahan dari kata Latin science yang secara etimologis berasal dari kata latin scinre, artinya to know. Dalam pengertian yang sempit science diartikan untuk menunjukkan ilmu pengetahuan alam yang sifatnya kuantitatif dan obyektif. Menurut Prof. Dr. Mohammad Hatta "tiap-tiap ilmu adalah pengetahuan yang teratur tentang pekerjaan hukum klausal dalam satu golongan masalah yang sama tabiatnya maupun menurut kedudukannya tampak dari luar maupun menurut bangunnya dari dalam”. Prof. Dr. A. Baiquni, guru besar Universitas Gajah Mada merumuskan bahwa "science merupakan general consensus dari masyarakat yang terdiri dari para scientist. ${ }^{22}$

Beberapa pengertian ilmu yang kami kemukakan diatas, dapat diperoleh gambaran yang jelas, apakah yang disebut dengan ilmu. Ilmu pada prinsipnya merupakan usaha untuk mengorganisasikan dan mesistematisasikan common sense, suatu pengetahuan yang berasal dari pengalaman dan pengamatan dalam kehidupan sehari-hari, namun dilanjutkan dengan suatu pemikiran secara cermat dan teliti dengan menggunakan berbagai metode. ${ }^{23}$

Ilmu dapat merupakan suatu metode berpikir secara obyektif, tujuannya untuk menggambarkan dan memberi makna terhadap dunia faktual. Pengetahuan yang diperoleh dengan ilm, diperolehnya melalui observasi, eksperimen, klasifikasi

\footnotetext{
${ }^{20}$ Juhaya S. Praja, Aliran-aliran filsafat dan etika, hal. 13.

${ }^{21}$ Burhanuddin Salam, hal. 9.

${ }^{22}$ Burhanuddin Salam, hal. 9.

${ }^{23}$ Burhanuddin Salam, hal. 10.
} 
dan analisis. Ilmu itu obyektif dan mengesampingkan unsur pribadi, pemikiran logika diutamakan, netral, dalam arti tidak dipengaruhi oleh sesuatu yang bersifat kedirian, karena dimulai dengan fakta, ilmu merupakan milik manusia secara komprehensif. ${ }^{24}$

Sebagaimana yang diutarakan al-Ghazali bahwa ilmu itu semata-mata milik Allah, sedang manusia diberi hak untuk mencari dan mengembangkannya sesuai kemampuan. Walaupun manusia mempunyai ilmu yang sedikit namun ilmu itu bisa dikembangkan supaya ilmu manusia bertambah dan bertambah.

Menurut Kamus Besar Bahasa Indonesia, pengertian ilmu diartikan sebagai pengetahuan tentang suatu bidang yang disusun secara sistematis menurut metode ilmiah tertentu yang dapat digunakan untuk menerangkan kondisi tertentu dalam bidang pengetahuan. Sedangkan dalam Wikipedia Indonesia, pengertian ilmu/ ilmu pengetahuan adalah seluruh usaha sadar untuk menemukan, menyelidiki dan meningkatkan pemahaman manusia dari berbagai bentuk kenyataan dalam alam manusia.

Ilmu (atau ilmu pengetahuan) adalah seluruh usaha sadar untuk menyelidiki, menemukan, dan meningkatkan pemahaman manusia dari berbagai segi kenyataan dalam alam manusia. Segi-segi ini dibatasi agar dihasilkan rumusanrumusan yang pasti. Ilmu memberikan kepastian dengan membatasi lingkup pandangannya, dan kepastian ilmu-ilmu diperoleh dari keterbatasannya. Ilmu bukan sekedar pengetahuan (knowledge), tetapi merangkum sekumpulan pengetahuan berdasarkan teori-teori yang disepakati dan dapat secara sistematik diuji dengan seperangkat metode yang diakui dalam bidang tertentu. Dari segi filsafat, ilmu terbentuk karena manusia berfikir lebih jauh mengenai pengetahuan yang dimilikinya.

Islam sangat memperhatikan, menghormati, dan menjunjung tinggi martabat ilmu dan orang yang memiliki ilmu, sebagaimana firman Allah SWT di dalam surat Al-Mujadilah/58:11 yang berbunyi:

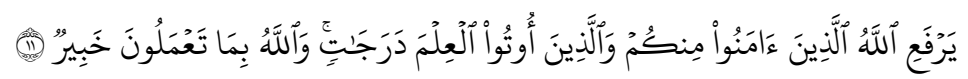

"...niscaya Allah akan meninggikan orang-orang yang beriman di antaramu dan orang-orang yang diberi ilmu pengetahuan beberapa derajat..." (Q.S. ALMujadilah/58:11)

Berangkat dari ayat diatas dikemukakan bahwa dalam ajaran Islam pengertian ilmu bukan hanya didasarkan pada jumlah ilmu yang dipelajarinya. Akan tetapi dapat dirasakan manfaatnya oleh manusia.

${ }^{24}$ Burhanuddin Salam, hal. 11, 
Menurut al-Qur'an cara memperoleh ilmu dalam pandangan al-Qur'an sebagaimana disyaratkan dalam Wahyu pertama Q.S. al-'Alaq/:4-5 yaitu: ilmu ladunni, ilmu yang diperoleh tanpa upaya manusia. ${ }^{25}$ Dan ilmu kasbi, yaitu ilmu yang diperoleh dengan usaha tangan manusia itu sendiri. ${ }^{26}$

Pada dasarnya, manusia memperoleh pengetahuan dari empat sumber yakni empirisme, rasionalisme, intuisi/Ladunni, dan wahyu: ${ }^{27}$

1. Empirisme, merupakan manusia yang mendasarkan dirinya kepada pengalaman yang mengembangkan paham. Menganggap bahwa dunia fisik adalah nyata karena merupakan gejala yang tertangkap oleh pancaindera. Tokoh-tokohnya antara lain John Locke, Barkeley, David Hume. Para penganut aliran empirisme tentu saja menentang kaum rasionalis yang begitu memberikan tempat dan peranan bagi akal dalam proses lahirnya pengetahuan. Mereka mengajarkan bahwa pengetahuan diperoleh lewat pengalaman. Peran rasio dalam pengetahuan kecil saja. Yang lebih menentukan adalah pengalaman indra. Akal hanya merupakan tempat penampungan yang secara positif menerima apa yang diterima indra. John Locke, filsuf Inggris, misalnya menyebut manusia dengan tabula rasa (papan yang kosong). Di atas papan yang kosong inilah dicatat pengalaman-pengalaman yang masuk lewat indra.

2. Rasionalisme, merupakan kaum rasionalis yang mengembangkan paham rasionalisme, dasar kepastian dan kebenaran pengetahuan. Para penganut rasionalisme tidak menyangkal peran indra, tetapi mengatakan bahwa peran indra sangat kecil. Yang lebih aktif justru rasio. Mereka mengatakan, pengetahuan manusia sebenarnya sudah ada lebih dulu dalam rasio berupa kategori-kategori. Ketika indra manangkap objek, maka objek-objek yang ditangkap itu hanya dicocokkan saja dengan kategori yang sudah ada lebih dulu dalam rasio. Jadi menurut mereka, pengalaman adalah pelengkap bagi akal. Kaum ini menggunakan metode deduktif dalam menyusun pengetahuannya, idenya didapatkan dari anggapan-anggapan yang menurutnya jelas dan dapat diterima. Tokoh-tokohnya kebanyakan para filsuf abad pertengahan, seperti Agustinus, Johanes Scotus, Avicenna, dan para filsuf modern seperti Rene Descartes, Spinoza,

\footnotetext{
${ }^{25}$ Muhammad Quraish Shihab, Wawasan al-Qur'an, hal. 573.

${ }^{26}$ Muhammad Quraish Shihab, Wawasan al-Qur'an, hal. 573.

${ }^{27}$ Yusuf Qardawi, Al-Qur'an Berbicara Tentang Aakal dan Ilmu Pengethuan, (Jakarta: Gema Insani, 2011), hal. 88.
} 
Leibniz, Fichte, Hegel. Plato, Galileo Galilei dan Leonardo Da Vinci juga termasuk kelompok ini.

3. Intuisi/Ladunni, merupakan manusia yang memperoleh pengetahuan yang tanpa melalui proses penalaran tertentu. Tanpa melalui proses berpikir berliku-liku tiba-tiba saja dia sudah sampai disitu. Paham ini diajarkan oleh Henri Bergon, sering filsuf Prancis. Bergson membedakan pengetahuan atas pengetahuan diskursif dan pengetahuan intuitif. Pengetahuan diskursif bersifat analitis, dan diperoleh melalui perantara simbol. Pengetahuan seperti ini dinyatakan dalam simbol, yakni bahasa. Jadi ini merupakan pengetahuan tidak langsung. Kalau saya menceritakan pengalaman saya, maka saya menggunakan bahasa. Jadi, pengetahuan yang diperoleh dengan cara ini bersifat tidak langsung. Sebaliknya pengetahuan intuitif bersifat langsung, sebab tidak dikomunikasikan melalui media simbol. Pengetahuan ini diperoleh lewat intuisi, pengalaman langsung orang yang bersangkutan. Jelas, pengetahuan seperti ini lebih lengkap. Ia menghadirkan pengalaman dan pengetahuan yang lengkap bagi orang yang mengalaminya. Tapi, alhasil pengetahuan jenis ini bersifat subyektif, sebab hanya dialami oleh orang tersebut. Menurut intuisionisme, pengetahuan yang lengkap hanya diperoleh lewat intuisi, yakni penglihatan langsung. Pada pengalaman itu orang seperti melihat kilatan cahaya yang memberikan kepadanya pengetahuan tentang sesuatu secara tuntas. Jadi, ini merupakan pengetahuan lengkap, sedangkan pengetahuan diskursif bersifat nisbih dan parsial. Jelaslah, bahwa sifat pengetahuan dalam intuisionisme lebih subyektif dibanding pengetahuan rasionalis dan empiris yang lebih objektif.

4. Wahyu, merupakan pengetahuan yang bersumber dari Tuhan melalui hamba-Nya yang terpilih untuk menyampaikannya (Nabi atau Rasul). Melalui wahyu, manusia diajarkan tentang pengetahuan, baik yang terjangkau maupun tidak terjangkau oleh manusia.

\section{Ilmu Laduni dan Penafsiran al Qur'an}

Setelah wafatnya Nabi Muhammad Saw. Para sahabatnya yang mendalami al-Qur'an, mengetahui berbagai rahasia yang tersirat dan yang telah menerima tuntunan serta petunjuk dari Nabi dan berikutnya sahabatnyalah yang menerangkan dan menjelaskan apa saja yang mereka ketahui dan pahami dari alQur'an, dalam kata lain setelah wafatnya Nabi, para sahabat mengambil bagian ini. Para sahabat juga memahami al-Qur'an, karena al-Qur'an diturunkan dalam bahasa mereka karena al-Qur'an diturunkan dalam bahasa Arab dan sesuai 
gaya bahasanya. Karena itu orang Arab memahaminya dan mengetahui maknamaknanya dengan baik, dalam kosa kata maupun susunan kalimatnya, meski demikian tidak semua orang Arab berasumsi sama dalam memahami ayat-ayat al-Qur'an dan terkadang sahabat yang satu memahami belum banyak dalam suatu ayat dan sahabat yang telah mengetahuui maksudnya. Ahli tafsir dari kalangan sahabat Nabi banyak jumlahnya tetapi yang terkenal luas hanya sepuluh orang, yaitu empat orang Khulafaur Rasyidin (Abu Bakar ash-Shiddieq, Umar bin Khaththab, Utsman bin Affan dan Ali bin Abi Thalib), Abdullah Ibnu Mas'ud, Ibnu Abbas, Ubay Ibnu Ka’ab, Zaid Ibnu Tsabit, Abu Musa al-Asy'ari, Abdullah Ibnu Zubair. Tercatat yang paling banyak diterima tafsirnya adalah khalifah yang keempat yaitu Ali bin Abi Thalib, dan diantara sepuluh sahabat Nabi tersebut yang memiliki gelar "ahli tafsir al-Qur'an" ialah Ibnu Abbas. Ibnu Abbas juga terkenal dengan sebutan “Turjuman al-Qur'an”(orang yang mahir menjelaskan al-Qur'an) dalam periode pembukaan tafsir, Ibnu Abbas dengan pendapatnya oleh ulama dikodifikasikan dan dinamakan tafsir Ibnu Abbas. ${ }^{28}$

Selanjutnya langkah tersebut diikuti oleh generasi berikutnya yaitu para tabi'in ${ }^{29}$ di beberapa daerah kekuasaan Islam. Pada masa ini muncul kelompok ahli tafsir di Mekkah, Madinah, Irak. Makkah merupakan paling banyak mufassir karena mereka pada umumnya adalah sahabat-sahabat Ibnu Abbas, kemudian di Irak, yakni sahabat-sahabat Ibnu Mas'ud. Di Madinah ada Zaid Ibnu Aslam yang menurunkan ilmunya kepada anaknya. Ibnu Zaid, kemudian kepada muridnya, Malik Ibnu Annas ra. ${ }^{30}$ Dari tabiin ini belajarlah generasi ketiga, para tabiin meneruskan pengetahuan tafsir yang mereka dapat dari kalangan tabiin pada zaman inilah diadakan kodifikasi di mulai pada akhir dinasti Bani Umayyah dan awal dinasti Abbasiyyah. Generasi ini mengumpulkan semua semua pendapat mutaqaddimun mereka kemudian dituangkan ke dalam kitab-kitab tafsir. ${ }^{31}$

Menurut para tokoh Islam seperti Al-Ghazali, ilmu itu terbagi dua bagian, yaitu ilmu bersifat kasbi dan ilmu yang bersifat laduni. ${ }^{32}$ Contoh ilmu yang tergolong dalam ilmu manusiawi (kasbi) yakni sains, yakni ilmu yang didapatkan

\footnotetext{
${ }^{28}$ Moenawar Kholil, Al-Qur'an dari Masa ke Masa, hal. 81.

${ }^{29}$ Tabiin adalah generasi yang bertemu dan bergaul dengan kalangan sahabat, yang beriman kepada Nabi dan meninggal dalam keadaan Iman.

${ }^{30}$ Pendiri Madzhab Malik terkenal dengan Imam Malik, kitab haditsnya yang masyhur adalah al-Muwatta, mengenahi Imam malik lihat sejarahnya dalam Muhammad Khudlari bek, Tarikh Tasyri Islami, (Beirut Libanon: Dar El Fikr,1967), hal. 203.

${ }^{31}$ Rif at Syauqi Nawawi. Rasionalitas Tafsir Muhammad Abduh, Kajian Masalah Aqidah dan Ibadah, (Jakarta: Paramadina, 2002), hal. 94.

${ }^{32}$ Baharuddin dan Wahyuni, E.N., Belajar dan Teori Belajar (Jogjakarta: Ar-Ruzz Media Group, 2010), hal, 32.
} 
oleh manusia melalui upaya yang dilakukannya. Ilmu seperti ini tidak pernah mencapai puncak kepastian, tapi hanya mendekatinya saja.

Ilmu Laduni itu buah ilmu dan amal, buah dzikir dan fikir, buah mujahadah dan riyadlah. Ilmu Laduni itu muncul di setiap saat sedang terjadi proses fikir (tafakkur), dalam rangka berusaha meningkatkan tahapan pencapaian ma'rifatullah. Disaat seseorang mengadakan penelitian terhadap konflik kehidupan yang sedang berkembang, terhadap rahasia di balik kehendak azaliah (qodho) dan keputusan yang hadits (taqdir). Dalam rangka membaca sinyal dan isyarah yang disebarkan oleh indikator-indikator yang terbaca melalui tambang proses terjadinya interaksi secara ruhaniah antara diri seorang hamba dengan urusan Tuhannya.

Di dalam kitab at-Tibyan fi Ulumil Qur'an, Imam Ali ash-Shobuni mengutip pendapat beberapa Ulama' tentang Ilmu Laduni ini, berkaitan dengan ihwal kebersihan hati, yang menjadi syarat mutlak untuk mendapatkan Ilmu Laduni.

As-Suyuthi berkata: Banyak orang mengira, bahwa Ilmu Laduni itu sangat sulit untuk didapat. Mereka berkata; Ilmu Laduni itu berada di luar jangkauan kemampuan manusia. Padahal sebenarnya tidaklah demikian. Untuk mendapatkan Ilmu Laduni itu, caranya hanya dengan jalan membangun sebabsebab yang dapat menghasilkan akibat. Adapun sebab-sebab itu adalah amal dan zuhud." Kemudian beliau meneruskan:

Ilmu-ilmu Al-Qur'an dan apa saja yang memancar darinya adalah sangat luas sekali. Bagaikan samudera yang tidak bertepi. Adapun Ilmu Laduni ini adalah alat yang mutlak bagi seseorang untuk menafsirkan ayat-ayat-Nya. ${ }^{33}$

Oleh karena itu, seseorang dilarang menafsirkan ayat-ayat al-Qur'an kecuali bagi mereka yang terlebih dahulu telah mendapatkan Ilmu Laduni ini. Barangsiapa menafsirkan al-Qur'an tanpa alat Ilmu Laduni ini, boleh jadi mereka hanya akan menafsirkanya dengan akal saja (bir ro'yi) yang dilarang oleh agama. Sebab, pemahaman ilmu al-Qur'an yang hakiki adalah sesuatu yang sifatnya Qodim dan sumber Ilmu Laduni juga dari yang Qodim itu. Oleh karena itu, orang tidak dapat menyentuh sesuatu yang Qodim kecuali dengan alat dari yang Qodim pula.

Di samping itu, ketika berhadapan dengan wacana tafsir, maka akan ditemukan dua pemetaan dari tafsir sebagaimana yang dipetakan oleh Abdul Mustaqim yakni tafsir sebagai produk dan tafsir sebagai proses. ${ }^{34}$ Jika tafsir dijadikan sebagai produk, maka ia (tafsir) merupakan bagian dari hasil atas pemikiran manusia terhadap al-Qur'an. Karena telah menjadi pemikiran manusia, maka

\footnotetext{
${ }^{33}$ Jalaluddin al-Suyuthi, Tafsir al-Qur'an al-Adzim, Juz 2, (Surabaya: Darul Abidin, T.t.)

${ }^{34}$ Abdul Mustaqim, Epistemologi Tafsir Kontemporer, hal. 32.
} 
konsekuensinya tafsiran dari al-Qur'an (kitab suci) tidaklah termasuk suci dan tidak absolut. Artinya sebuah karya tafsiran misalnya dari konteks masa lalu belum tentu relevan dengan konteks masa sekarang dan yang akan datang. ${ }^{35}$

Sementara jika tafsir menjadi sebuah proses, maka ia (tafsir) merupakan proses mendialogkan antara teks (al-Qur'an) dengan konteks (realitas). Hal ini dikarenakan al-Qur'an yang sebagai pedoman hidup (lihat QS. al-Baqarah/2:185) senantiasa berbenturan dengan problem realitas yang terus berubah dan berkembang. Dengan demikian, tafsir sebagai proses menjadi sebuah kegiatan yang harus terus berlangsung sepanjang zaman. ${ }^{36}$

Dengan demikian ilmu yang diterima langsung oleh hati manusia melalui ilham, iluminasi (penerangan) atau inspirasi dari sisi Tuhan disebut ilmu laduni. Pengetahuan yang diperoleh seseorang yang saleh dari Allah SWT melalui ilham dan tanpa dipelajari lebih dahulu melalui suatu jenjang pendidikan tertentu. Oleh sebab itu, ilmu tersebut bukan hasil dari proses pemikiran, melainkan sepenuhnya tergantung atas kehendak dan karunia Allah SWT.

Di dalam ilmu tasawuf dibedakan tiga jenis alat untuk komunikasi rohaniah, yakni pertama kalbu (hati nurani) untuk mengetahui sifat-sifat Tuhan, kedua roh untuk mencintai-Nya dan ketiga bagian yang paling dalam yakni sirr (rahasia) untuk musyahadah (menyaksikan keindahan, kebesaran, dan kemuliaan Allah SWT secara yakin sehingga tidak terjajah lagi oleh nafsu amarah). Meski dianggap memiliki hubungan misterius dengan jantung "secara jasmani", kalbu bukanlah daging atau darah, melainkan suatu benda halus yang mempunyai potensi untuk mengetahui esensi segala sesuatu. Lapisan dalam dari kalbu disebut roh; sedangkan bagian terdalam dinamakan sirr, kesemuanya itu secara umum disebut hati. Apabila ketiga organ tersebut telah disucikan sesuci-sucinya dan telah dikosongkan dari segala hal yang buruk lalu diisi dengan dzikir yang mendalam, maka hati itu akan dapat "memahami” Allah.

Pada konteks itu, Allah akan melimpahkan nur cahaya keilahian-Nya kepada hati yang suci ini. Hati seperti itu diumpamakan oleh kaum Sufi dengan sebuah cermin. Apabila cermin tadi telah dibersihkan dari debu dan noda-noda yang mengotorinya, niscaya ia akan mengkilat, bersih dan bening. Pada saat itu cermin tersebut akan dapat memantulkan gambar apa saya yang ada dihadapannya.

Demikian juga hati manusia. Apabila ia telah bersih, ia akan dapat memantulkan segala sesuatu yang datang dari Allah. Pengetahuan seperti itu disebut makrifat musyahadah atau ilmu laduni. Semakin tinggi makrifat seseorang semakin banyak pula ia mengetahui rahasi-rahasia Allah dan ia pun semakin "dekat" dengan $18-19$.

${ }^{35}$ Abdul Mustaqim, Pergeseran Epistemologi Tafsir, (Yogyakarta: Pustaka Pelajar, 2008), hal.

${ }^{36}$ Abdul Mustaqim, Pergeseran Epistemologi Tafsir, hal. 5-7. 
Tuhan. Meskipun demikian, memperoleh makrifat atau ilmu laduni yang penuh dengan rahasia-rahasia ketuhanan tidaklah mungkin karena manusia serba terbatas, kecuali manusia itu melakukan riadhah dan Allah memang menghendakinya.

Menurut Ibnu Katsir ayat tersebut (Q.S. al-Kahfi/18:65) ditafsirkan bahwa; Nabi Musa berkata kepada pemuda yang bernama Yusya' bin Nun. Nabi Musa memberi tahu kepada pemuda tersebut kalau ada seorang hamba Allah SWT ditempat pertemuan dua laut, dia mempunyai ilmu pengetahuan yang tidak dimiliki oleh Nabi Musa yaitu ilmu ghaib. Ketika itupun Nabi Musa tertarik untuk pergi ketempat tersebut. Dia berkata kepada Yusya' aku akan terus berjalan sebelum sampai kepertemuan dua buah lautan. ${ }^{37}$

\section{Kesimpulan}

Dari uraian di atas dapat disimpulkan dua hal pokok, yakni:

1. Secara umum Ilmu Ladunni adalah sebuah pengetahuan yang dianugerahkan (diwariskan) Allah kepada manusia yang mengamalkan pengetahuan yang ia peroleh dan berbuat menurut pemahaman yang ia capai ('amila bima 'alima). Keilmuan ini dapat diperoleh siapapun dengan memenuhi syaratsyarat yang telah dipaparkan. Syarat utama dan pertama adalah kebersihan hati dari kotoran-kotoran dosa, sombong, ego, dan nilai-nilai negatif lainnya. Kemudian diikuti dengan mengamalkan pengetahuan yang telah dimilikinya. Sedangkan tanda-tanda orang yang memperoleh Ilmu Ladunni antara lain adalah komitmennya yang tinggi dalam perilaku kemanusiaan untuk membela kebenaran dan berusaha mewujudkannya dalam kehidupan masyarakat.

2. Dalam persoalan teks, Ilmu Ladunni secara fungsional memiliki dua wilayah kerja pokok, yakni wilayah teks (objek/internal) dan wilayah pengkaji (subjek/eksternal). Dalam wacana tafsir, teks adalah al-Qur'an dan pengkaji adalah mufassir (dan juga pembaca).

Ilmu Laduni pada masa klasik dipahami sebagai ilmu ghaib karena ditafsiri secara tekstual saja. Pada masa ini penafsiran berbasis Quasi kritis, dan didominasi dengan tafsir bil ma'tsur yang dimulai sejak Nabi Muhammad SAW sampai generasi ulama' Mutaqaddimin atau sejak kemunduran Islam yaitu jatuhnya Baghdad pada tahun $656 \mathrm{H} / 1258 \mathrm{M}$. sedangkan pada zaman modern hingga sekarang yang dimulai sejak gerakan modern Islam di Mesir oleh Jamaluddin alAfgani pada tahun $1254 \mathrm{H} / 1838$ M. para mufassir modern Islam di Mesir dalam menafsirkan al-Qur'an lebih menjelaskan bahwa Islam tidak bertentangan dengan hal. 49 .

${ }^{37}$ Ibnu Katsir, Tafsir Katsir, Abd. Ghoffar dkk, jilid 4 (Jakarta: Pustaka Imam Syafi'I, 2009), 
ilmu pengetahuan dan kemoderenan. Islam adalah agama universal yang sesuai dengan seluruh bangsa pada semua masa dan setiap tempat.

Al-Suyuthi menyebutkan ada lima belas disiplin yang harus dikuasai oleh seorang mufassir, yaitu: 1) Bahasa., 2) Nahwu., 3) al-Tasrif., 4) al-Isytiqaq., 5) alMa'ani., 6) al-Bayan., 7) al-Badi'., 8) Ilmu Qira'ah., 9) Ushul al-Din., 10) Ushul Fiqh., 11) Asbab al-Nuzul., 12) Nasikh-Mansukh., 13) Fiqh., 14) Keteranganketerangan (Hadits-hadits [Ahadits]) yang menjelaskan mujmal-mubayyan ayat., dan 15) Ilmu Laduni atau ilmu Laduni.

Fungsi, konsep terhadap teks al-Qur'an ada tiga, yakni: a. Mengungkap halhal batin (asrar) dari objek., b. Mencapai titik tertinggi dari upaya manusia dalam memahami teks dan objek., dan c. Menghindari ketidaktepatan pemahaman dan pemaknaan atas sebuah teks/objek. Sedangkan fungsi terhadap pengkaji/mufassir juga ada tiga, yakni: a. Sebagai kontrol moral bagi para pelaku., b. Menunjukkan kebesaran dan kekuasaan-Nya sekaligus menampakkan keterbatasan kemampuan subjek., dan c. Ma'rifat bi-l-lah.

Ilmu Ladunni ini memiliki posisi yang sangat penting dalam upaya penafsiran al-Qur'an, dan pentingnya pemahaman jenis keilmuan ini (ilmu Ladunni) bagi para mufassir.

Oleh karena itu, disinilah Ilmu Ladunni mendapatkan posisinya sedemikian penting dalam upaya penafsiran al-Qur'an. Ilmu Ladunni menjadi bagian yang tak dapat dipisahkan dan menjadi keniscayaan. Dengan demikian kontribusi penulisan tesis ini adalah pemaparan kembali konsep Ilmu Ladunni untuk menunjukkan pentingnya peranan dalam penafsiran al-Qur'an, mengingat mulai terlupakannya keilmuan ini, karena dimana, dalam penafsiran keilmuan ini diperlukan guna mengungkap makna ayat berikut rahasia-rahasianya. Mengutip pendapat sahib al-Burhan, yakni al-Zarkasyi, tanpa ilmu ini makna dan rahasia ayat-ayat-Nya tidak akan terungkap oleh para pengkaji dan pemerhati al-Qur'an.

\section{Daftar Pustaka}

Al-Ghazali, Ihya Ulumuddin, Beirut: Dar al Fikr, t.t.

M. Quraish Shihab, Tafsir al-Misbah Pesan dan Kesan al-Qur'an, (Jakarta: Lentera Hati, 2002

Syaikh Muhammad Ali Ash-Shabuni, Syafwatutu Tafasir, Terj. Yasin. Vol. 3, Jakarta: Pustaka al-Kautsar, 2011

Syaikh Muhammad Ali Ash-Shabuni, Syafwatutu Tafasir, Beirut; Alim al Kutub1985

Nasaruddin Baidan, Perkembangan Tafsir al-Qur'an di Indonesia; Solo: Tiga Serangkai, 2003 
Ahmad bin Muhammad al-Dhimyathi, Kaum Sufi dan Pemikirannya; Bandung: Nusa Medua, 2005

Al-Ghazali, Ar-Risalah al-Ladunniyyah, (Terj.) Yogyakarta: Mitra Pustaka, 2004

Muhammad 'Abd al-'AzIm al-Zarqani, Manahil al-Irfan fi 'Ulum al-Qur'an, Jilid II, Beirut: Dar al-Fikr, t. th.

Musa Asy'arie, Filsafat Islam: Sunnah Nabi Dalam Berpikir (Jogjakarta: LESFI, Cet. III ; 2002

Musa Asy'arie, Filsafat Islam: Sunnah Nabi Dalam Berpikir, hal. 56.

Jalaluddin al-Suyuthi, al-Itqon fi Ulum al-Qur'an Beirut: Dar al-Kutub al-Ilmiyah, 1987

Syekh Nawawi Al-jawi, Marah Labid Tafsir An-Nawawi, Surabaya: Al-Hidayah

Sayyid Muhammad Qutb, Tafsir Fi Zhilal Al-Quran, Beirut: Dar Al-Syuruq, 1992

Juhaya S. Praja, Aliran-aliran filsafat dan etika, (Jakarta: Prenada Media, Jakarta Timur, 2003

Yusuf Qardawi, Al-Qur'an Berbicara Tentang Aakal dan Ilmu Pengethuan, Jakarta: Gema Insani, 2011

Muhammad Khudlari bek, Tarikh Tasyri' Islami, Beirut Libanon: Dar El Fikr,1967

Rif at Syauqi Nawawi. Rasionalitas Tafsir Muhammad Abduh, Kajian Masalah Aqidah dan Ibadah, Jakarta: Paramadina, 2002

Baharuddin dan Wahyuni, E.N., Belajar dan Teori Belajar, Jogjakarta: Ar-Ruzz Media Group, 2010

Jalaluddin al-Suyuthi, Tafsir al-Qur'an al-Adzim, Juz 2, Surabaya: Darul Abidin, T.t.

Abdul Mustaqim, Pergeseran Epistemologi Tafsir, (Yogyakarta: Pustaka Pelajar, 2008

Ibnu Katsir, Tafsir Katsir, Abd. Ghoffar dkk, jilid 4, Jakarta: Pustaka Imam Syafi'I, 2009 
238 Mumtäz Vol. 2 No. 2, Tahun 2018 